\title{
EFFECT OF AUXINS SUPPLEMENTATION ON CALLUS INDUCTION AND ROOT REGENERATION IN BANANA (Musa paradisiaca L.) cv. UDHAYAM UNDER in vitro CULTURES
}

\author{
Shardulya Shukla ${ }^{1 *}$, Yogesh Rajbhar ${ }^{1}$, Ankita Sharma ${ }^{2}$, Pushpender Bhardwaj ${ }^{2}$, \\ Vivek Kumar Tiwari ${ }^{2}$, Harendra Tiwari ${ }^{1}$, Manoj Kumar ${ }^{1}$, Ashish Kumar ${ }^{1}$
}

${ }^{1}$ Department Horticulture, Sardar Vallabhbhai Patel University of Agriculture \& Technology, Meerut, India -250 110 (U.P.), India.

${ }^{2}$ Defence Institute of High Altitude Research, DRDO, Chandigarh.

Received - October 01, 2019; Revision - January 15, 2020; Accepted - February 05, 2020

Available Online - February 25, 2020

DOI: http://dx.doi.org/10.18006/2020.8(1).30.34

KEYWORDS
Banana
Micropropagation
Explants
Sword sucker
Auxin
Callus

* Corresponding author

E-mail: shardulyashukla@gmail.com (Shardulya Shukla)

Peer review under responsibility of Journal of Experimental Biology and Agricultural Sciences.

Production and Hosting by Horizon Publisher India [HPI] (http://www.horizonpublisherindia.in/).

All rights reserved.

\begin{abstract}
Present study was conducted to study the effect of different auxins concentration on callus induction and root regeneration in Musa paradisiaca L. cv. Udhayam. MS media supplemented with 2, 4-D alone $\left(2.00,3.00,4.00,5.00,6.00, \mathrm{mgl}^{-1}\right)$ was used for induction of callus whereas MS media was supplemented with nine combinations of IBA and NAA were used for regeneration of roots from induced callus. Result of study revealed that minimum time (24.41 days) of callus induction was observed in 2,4-D (4.00 $\left.\mathrm{mgl}^{-1}\right)$; whereas maximum time (39.42 days) was noted in control. Further, combination of IBA $\left(2.50 \mathrm{mgl}^{-1}\right)$ and NAA, $\left(2.00 \mathrm{mgl}^{-1}\right)$ also have significant effect on the root proliferation in banana shoots. Minimum days taken for root initiation (11.73 days) were found in IBA $\left(2.50 \mathrm{mgl}^{-1}\right)$ and NAA (2.00 $\left.\mathrm{mgl}^{-1}\right)$ combination. Similarly, maximum number of roots (7.03) and maximum rooting percent $(87.30 \%)$ per plantlet was recorded under the treatment of IBA $\left(2.5 \mathrm{mgl}^{-1}\right)$ and NAA $\left(2.00 \mathrm{mgl}^{-1}\right)$. Therefore from the results of current study it can be concluded that 2,4-D with concentration of $4.00 \mathrm{mgl}^{-1}$ has good response for callus induction whereas the combination of IBA $\left(2.50 \mathrm{mgl}^{-1}\right)$ and NAA $\left(2.00 \mathrm{mgl}^{-1}\right)$ was found better for regeneration of roots.
\end{abstract}

All the articles published by Journal of Experimental Biology and Agricultural Sciences are licensed under a Creative Commons Attribution-NonCommercial 4.0 International License Based on a work at www.jebas.org.

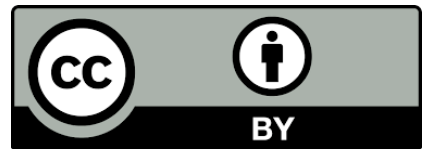




\section{Introduction}

Banana ("Adam fig", "Apple of Paradise"), is one of the oldest fruit of the world which belongs to Musaceae family. Botanically it is classified as Musa paradisiaca. edible banana has been reported to be originated in warm and moist part of South East Asia, possibly in the hilly regions of Assam, Burma, Thailand or Indo-China. In addition to being staple food crop for millions of people, it is also most commercial fruit crop of tropical areas all around the world (Singh \& Saxena 2008).

Fruit of banana is popular for its aroma and luscious texture. It is considered as nutritious 'gold mine' as it is rich in carbohydrates and vitamins particularly vitamin B6. It contains carbohydrate, crude fibre, protein, ash, potassium, phosphorus, calcium, iron, magnesium, riboflavin, niacin and ascorbic acid (FAO, 2014). Regular consumption of banana fruit helps in reducing the risk of heart diseases and is recommended for patients suffering from high blood pressure, arthritis, ulcer, gastroenteritis and kidney disorders (Dayarani et al., 2013).

In India banana fruit covers an area of 8.58 million hectare, producing 29.16 million tonnes with a productivity of 33.98 MT/ha during the year 2016-17 (Indian Horticulture N H B Data base 2016-17). In India, Gujarat ranks first in production followed by Andhra Pradesh, Tamil Nadu and Uttar Pradesh. However, productivity was recorded highest in Madhya Pradesh followed by Gujarat and Punjab (Indian Horticulture N H B Data base 2016-17).

Most commonly propagated banana species are triploid and derived from two diploid species M. acuminata (Malaysia) and M. balbisiana (India) (Ali et al., 2011) and it is propagated vegetative through sword suckers and other planting materials like bits, butts and peepers (Uma et al., 2010); However, quality planting material is the key factor responsible for successful production of banana. Development of tissue culture technology has been proved as one of the foundation for production of high quality, disease free planting materials on a large scale, particularly in vegetatively propagated crops like banana. In vitro propagation is a magnificent approach for the production of good planting material of banana at low price with the potential of producing 50-60 shoots per sucker in 4-5 months (Georget et al., 2000). Tissue cultured plants have been reported to produce 39 per cent higher yield than plants from sword suckers (Farahani et al., 2008). Every year, approximately 2500 million plants are requisite for cultivation of banana in India, but only 2.5 per cent of the total requirements are fulfilled. Therefore, keeping this in view, present study was conducted to assess the effect of auxins on callus induction and root regeneration in banana $(M$. paradisiaca $\mathrm{L}$.) cv. Udhayam under in vitro cultures.

\section{Material and Methods:}

\subsection{Preparation of MS media}

All chemicals were purchased from Himedia and all solution was prepared in double distilled water. Murashige \& Skoog 1962 (MS) media was prepared with growth regulators viz., auxins (2,4-D, IBA and NAA) according to the treatment requirement. Firstly, the stock solution of MS media and plant growth regulators $(2,4-\mathrm{D}$, IBA and NAA) were prepared by weighing the required amount of the chemicals using digital balance and dissolved them in sterilized double distilled water. MS media supplemented with 2, 4-D alone (2.00, 3.00, 4.00, $5.00,6.00, \mathrm{mgl}^{-1}$ ) was used for induction of callus whereas MS media was supplemented with nine combinations of IBA and NAA i.e. $2.00 \mathrm{mgl}^{-1} \mathrm{IBA}+1.00 \mathrm{mgl}^{-1} \mathrm{NAA} ; 2.00 \mathrm{mgl}^{-1} \mathrm{IBA}+$ $2.00 \mathrm{mgl}^{-1} \mathrm{NAA} ; 2.00 \mathrm{mgl}^{-1} \mathrm{IBA}+2.50 \mathrm{mgl}^{-1} \mathrm{NAA} ; 2.50 \mathrm{mgl}^{-}$ ${ }^{1} \mathrm{IBA}+1.00 \mathrm{mgl}^{-1} \mathrm{NAA} ; 2.50 \mathrm{mgl}^{-1} \mathrm{IBA}+2.00 \mathrm{mgl}^{-1} \mathrm{NAA}$; $2.50 \mathrm{mgl}^{-1} \mathrm{IBA}+2.50 \mathrm{mgl}^{-1} \mathrm{NAA} ; 3.00 \mathrm{mgl}^{-1} \mathrm{IBA}+1.00 \mathrm{mgl}^{-1}$ NAA; $3.00 \mathrm{mgl}^{-1} \mathrm{IBA}+2.00 \mathrm{mgl}^{-1} \mathrm{NAA}$ and $3.00 \mathrm{mgl}^{-1} \mathrm{IBA}+$ $2.50 \mathrm{mgl}^{-1} \mathrm{NAA}$ were used for regeneration of roots from induced callus. MS media was prepared by addition of requisite stock solution, growth regulators, sucrose (30 gm/litre) and agar ( $8 \mathrm{gm} /$ liter) as per standard procedure. $\mathrm{pH}$ of the medium was adjusted to 5.8 and all culture containers filled with media autoclaved at $121.6^{\circ} \mathrm{C}$ at 15 psi for 20 minutes.

\subsection{Sterilization of explant}

Sword sucker were used as explants for initiation of callus culture. Selected explants were washed thoroughly under running tap water for half an hour to separate on mother plant. Explant was surface sterilized by using ethyl alcohol (70\%) for a period of 5 minutes followed by thoroughly washed with double distilled water. This process was carried out to remove the adhering chemicals on the surface of the explants.

\subsection{Preparation of explant and culturing on MS media}

Explant was inoculated in test tubes under aseptic conditions of laminar air flow chamber. Further, inoculated culture vessels were kept under light intensity of $30.0 \mu \mathrm{m} \mathrm{dm}-1 \mathrm{~s}-1$ white light fluorescence tubes and temperature of $25 \pm 2{ }^{\circ} \mathrm{C}$ with humidity at 65 $\%$, photoperiod of (2000- 3000 lux) of 16 hours light and 8 hours dark in culture room.

\subsection{Data analysis}

One-way ANOVA was used for analysis of callusing data whereas two-way ANOVA was used for analysis for rooting data. 


\section{Results and Discussion}

\subsection{Initiation of callus}

Six different combination of 2,4-D was investigated for induction of callus. Significant enhancement (days) in average callus induction was observed from 24.41 to 39.42 days after inoculation. Minimum time (24.41 days) of callus induction was observed using 2,4-D @ $4.00 \mathrm{mgl}^{-1}$ concentration, it was followed by 2,4-D $3.0 \mathrm{mgl}^{-1}$ (26.76 days), 2,4-D $6.0 \mathrm{mgl}^{-1}$ (27.90 days) and 2,4-D 2.0 $\mathrm{mgl}^{-1}$ (28.73 days) respectively, while maximum time (39.42 days) for callus induction was observed in untreated explants (Figure $1 \&$ 2). The same pattern of observations was recorded by Darvari et al. (2010), Rashid (2012), Kumar et al. (2013), Sultan et al. (2011), Jafari et al. (2011) and Shukla et al., (2018).

\subsection{In vitro establishment of root}

\subsubsection{Days taken for root initiation:}

Effect of IBA and NAA on time taken for root initiation was observed for period of 25 days. Minimum time (11.733 days) was observed in MS medium supplemented with NAA $\left(2.00 \mathrm{mgl}^{-1}\right.$ and IBA $2.5 \mathrm{mgl}^{-1}$ ) where as maximum time duration (22.77days) was observed in MS medium supplemented with only $3.0 \mathrm{mgl}^{-1}$ IBA (Figure 3). Further it has been observed that increase in concentration of IBA has also increased the time duration for root initiation. From these results it was concluded that IBA is able to initiate root only in presence of optimum concentration of NAA. The same pattern of performance was observed by Sultan et al. (2011), Kumar et al. (2013), Jafari et al. (2011), Karule et al. (2016), Ali \& Mehmood (2017) and Nandhakumar et al. (2018).

\subsubsection{Number of roots per plantlet}

It was evident from the data that there was significant increase in number of roots per plantlet treated with suitable combinations of NAA and IBA in MS medium. The current study revealed that maximum number of roots (7.03) per plantlet was recorded in established culture treated with IBA, $\left(2.50 \mathrm{mgl}^{-1}\right)$ and NAA, $\left(2.00 \mathrm{mgl}^{-1}\right)$ followed by $6.16,6.03$ and 5.96 with the treatments of IBA, $\left(2.00 \mathrm{mgl}^{-1}\right)+\mathrm{NAA},\left(2.00 \mathrm{mgl}^{-1}\right)$; IBA, $\left(2.00 \mathrm{mgl}^{-1}\right)+\mathrm{NAA}$, $\left(1.00 \mathrm{mgl}^{-1}\right)$; IBA, $\left(3.00 \mathrm{mgl}^{-1}\right)+\mathrm{NAA},\left(2.00 \mathrm{mgl}^{-1}\right)$ and IBA, $\left(2.00 \mathrm{mgl}^{-1}\right)$ respectively; whereas minimum number of roots (1.30) was recorded in MS media supplemented with IBA, (3.00 $\mathrm{mgl}^{-1}$ ) (Figure 4). These results also correlated with the previous experiment and validated that number of roots per plantlet also increased in MS medium supplemented with optimum concentration of IBA and NAA. Therefore IBA $\left(2.50 \mathrm{mgl}^{-1}\right)$ and NAA $\left(2.00 \mathrm{mgl}^{-1}\right)$ was selected for maximum proliferation of roots (Figure 4). The same pattern of root development was noted by Sultan et al. (2011), Kumar et al. (2013), Jafari et al. (2011), Lohidas \& Sujin (2015) and Karule et al. (2016).

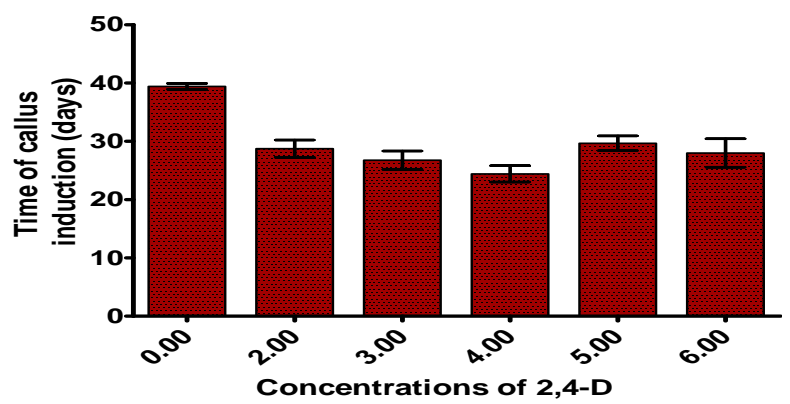

Figure 1 Effect of different concentrations of 2, 4-D with MS media on time of callus induction inoculation (days) in banana cv. Udhayam

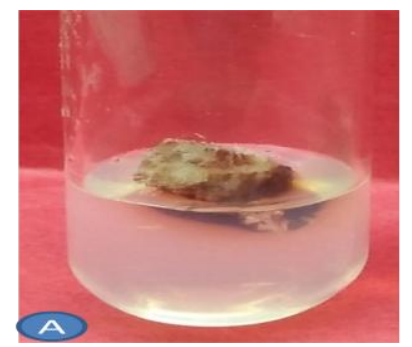

Figure 2 A. Initiation of callus.

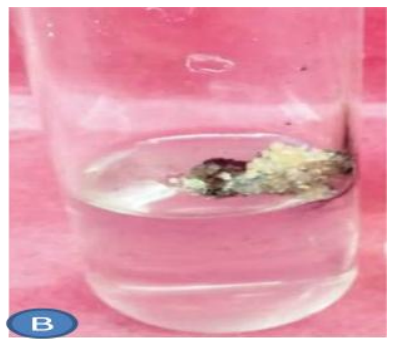

B. Proliferation of callus.

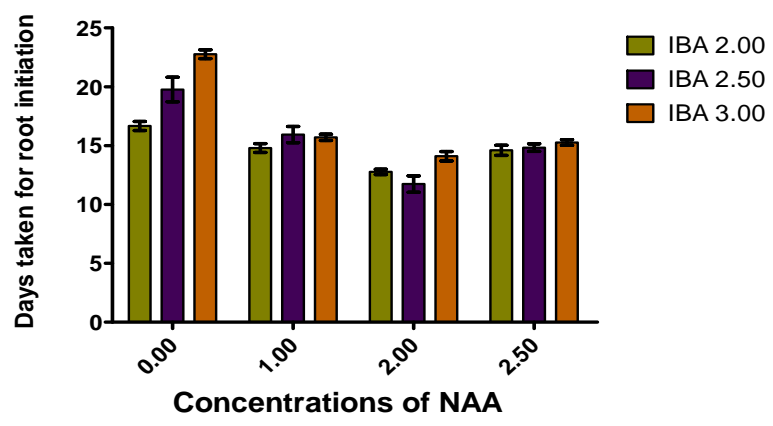

Figure 3 Effect of IBA and NAA on days taken for root initiation of banana cv. Udhayam under MS medium

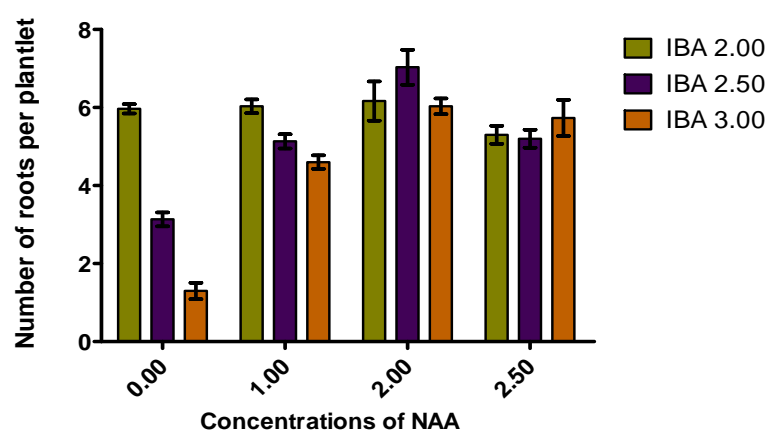

Figure 4 Effect of different concentrations of IBA and NAA on rooting of shoots $(\%)$ in plantlet regenerated in-vitro after 40 days (5 weeks) under MS medium 


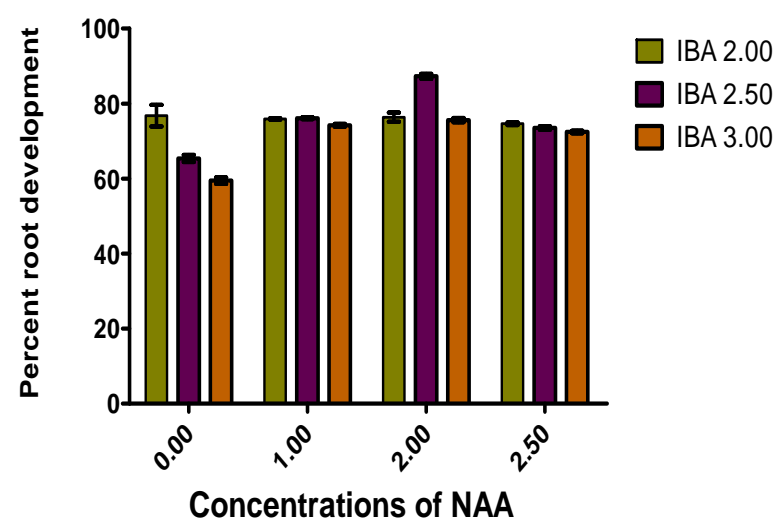

Figure 5 Effect of IBA and NAA on number of roots per plantlets of established culture of banana cv. Udhayam under MS medium

\subsubsection{Percent root formation per shoot after 40 days}

The data pertaining to percentage of roots per shoot development for primordial emergence are presented with suitable combination of IBA and NAA in MS medium. The current study revealed that maximum rooting percent was observed $(87.30 \%)$ in plantlet of established culture treated with IBA, $\left(2.50 \mathrm{mgl}^{-1}\right)+\mathrm{NAA},(2.00$ $\mathrm{mgl}^{-1}$ ) followed by $76.78,76.36$ and 76.10 with the treatments of IBA, $\left(2.00 \mathrm{mgl}^{-1}\right)$ alone, IBA $\left(2.00 \mathrm{mgl}^{-1}\right)+\mathrm{NAA}\left(2.00 \mathrm{mgl}^{-1}\right)$ and IBA $\left(2.50 \mathrm{mgl}^{-1}\right)+$ NAA $\left(1.00 \mathrm{mgl}^{-1}\right)$ respectively, where as minimum percentage of roots per shoot $(59.46 \%)$ was recorded in IBA $\left(3.00 \mathrm{mgl}^{-1}\right.$ ) treated explants (Figure $5 \& 6$ ). The result is similar to the findings of Govindaraju et al. (2012), Kalimuthu et al. (2007), Liu xuenhong et al. (2006), Karule et al. (2016) and Nandhakumar et al. (2018).

Minimum time duration (24.41 days) for induction of callus was obtained in MS medium supplemented with 2,4-D (4.00 $\mathrm{mgl}^{-1}$ ). Minimum days taken for root initiation (11.73 days) were found using IBA, (2.50 mgl $\left.{ }^{-1}\right)$ and NAA, $\left(2.00 \mathrm{mgl}^{-1}\right)$ combination. Maximum number of roots (7.03) and maximum rooting percent $(87.30 \%)$ per plantlet was recorded under the treatment of IBA, $\left(2.5 \mathrm{mgl}^{-1}\right)$ and NAA, $\left(2.00 \mathrm{mgl}^{-1}\right)$. Therefore in this study it has been concluded that 2,4-D with concentration of $4.00 \mathrm{mgl}^{-1}$ has shown good response for callus induction whereas the combination of IBA (2.50 mgl $\left.{ }^{-1}\right)$ and NAA $\left(2.00 \mathrm{mgl}^{-1}\right)$ was found better for regeneration of roots.

\section{Acknowledgement}

The authors are highly thankful to tissue culture laboratory of Department of Horticulture of Sardar Vallabhabhai Patel University of Agriculture and Technology, Meerut for providing the facilities to conduct the experiment.

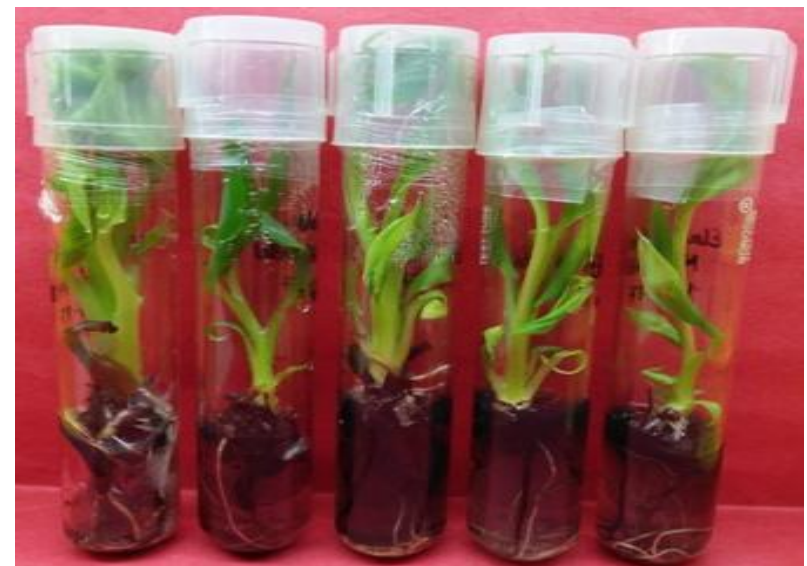

Figure 6 Root proliferation in MS medium supplemented with 2.50 $\mathrm{mgl}^{-1}$ and NAA, $2.00 \mathrm{mgl}^{-1}$

\section{Conflict of Interest}

Authors would hereby like to declare that there is no conflict of interests that could possibly arise.

\section{References}

Ali A, Sajid A, Naveed NH, Abdul M, Asif S, Umair AK, Fisal IJ, Naz $S$ (2011) Initiation, proliferation and development of micropropagation system for mass scale production of banana through meristem culture. African Journal of Biotechnology 10: 15731-15738.

Ali S, Mehmood S (2017) Micro Propagation of cv. Basrai (Banana) Using Growth Hormones. Journal of Horticulture 4: 195-196.

Darvari FM, Sariah M, Pau MP, Maziah M (2010) Micropropagation of some Malaysian banana and plantain (Musa spp.) cultivars using male flowers. African Journal of Biotechnology 9: 2360-2366.

Dayarani M, Dhanarajan MS, Uma S, Durai P (2013) Macropropagation for regeneration of wild bananas (Musa spp.). Advanced Bio Tech 12: 16-18.

FAO STATS (2014) available on http://www.fao.org/statistics/en/2014 access on 25 October, 2019.

Farahani F, Aminpoor H, Sheidai MZ, Noormohammadi Z, Mazinani MH (2008) An Improved System for in vitro Propagation of Banana (Musa acuminate L.) cultivars. Asian Journal of Plant Science 7: 116-118.

Georget F, Domergue RR, Ferriere N, Cote FX (2000) Morpnohistological study of the different constituents of a banana (Musa AAA, cv. Grand naine) embryogenic cell. Plant Cell Organ Culture 33: 343-346. 
Govindaraju S, Saravanan J, Jayanthi B, Nancy D, Arulselvi I Lohidas J, Sujin D (2015) Effect of growth hormones in the (2012) In Vitro propagation of Banana (Musa sp- Rasthali variety) from sword suckers for its commercial production. Research in Plant Biology 2: 2231-5101.

Indian horticulture data base (2016-17) National Horticulture Board. http//www.nhb.org.

Jafari N, Othman RY, Khalid N (2011) Effect of Benzylamino purine (BAP) pulsing on in vitro shoot multiplication of Musa acuminata (banana) cv. Berangan. African Journal of Biotechnology 10: 2446-2450.

Kalimuthu K, Saravanakumar M, Senthilkumar R (2007) In vitro micropropagation of Musa Sapientum L. (Cavendish dwarf). African Journal of Biotechnology 6: 1106-1109.

Karule P, Dalvi V, Kadu A, Chaudhari R, Subramaniam VR, Patil $\mathrm{AB}$ (2016) A commercial micropropagation protocol for virupakshi $(\mathrm{AAB})$ banana via apical meristem. African Journal of Biotechnology 15: 401-407.

Kumar D, Anbazhagan M, Rajendran R (2013) In Vitro propagation of Banana (Musa acuminate L.) cv. Cavandish Dwarf. International Journal of Research in Biomedicine and Biotechnology 3: 44-46.

Liu Xuenhung, Kunlin W, Guoltua C, Zhilin C, Jun D, Jun Z S (2006) Tissue culture techniques and rapid propagation of banana cultivar gold finger. South China Fruits 1: 34-35.

micropropagation of banana cv. Matti. Plant Archives 15: 307-314.

Murashige T, Skoog F (1962) A revised medium for rapid growth and bio assays with tobacco tissue cultures. Physiologia plantarum 15: 473-497.

Nandhakumar N, Kumar K, Sudhakar D, Soorianathasundaram K (2018) Plant regeneration, developmental pattern and genetic fidelity of somatic embryogenesis derived Musa spp. Journal of Genetic Engineering and Biotechnology 16: 587-598.

Rashid A. (2012) Cell physiology and genetics of higher plant 1: CRC Press, Boca Raton, Fla.,1: 67-107.

Shukla S, Prasad Y, Yadav AK, Dixit P, Patel B, Yadav V (2018) Effect of different auxins and cytokinins in callus induction and shoot regeneration in banana (Musa paradisiaca L.) variety Udhayam under in vitro condition. International Journal of Chemical Studies 6: 2041-2045.

Singh R, Saxena SK (2008) Fruits. National Book Turst, New Delh, India. ISBN 978-81-237-0150-9.

Sultan MT, Khan MH, Hakim ML, Mamun ANK, Morshed MA, Islam MR, Islam MR (2011) In vitro plant regeneration from male flowers of banana. International Journal of Biosciences 1: 1-11.

Uma S, Sajith KP, Saraswathi KP, Durai P (2010) Macropropagation - A Farmer's Friendly Technology. Technical Bulletin no. 18: 1-2. 